\title{
In Vitro Cytotoxic Activity of a Lactococcus lactis Antimicrobial Peptide Against Breast Cancer Cells
}

\author{
Abasaleh Avand, Vajihe Akbari *, Shahin Shafizadegan \\ Department of Pharmaceutical Biotechnology and Isfahan Pharmaceutical Research Center, Faculty of Pharmacy, Isfahan University of \\ Medical Sciences, Isfahan, Iran
}

"Corresponding author: Vajihe Akbari, Department of pharmaceutical Biotechnology, Isfahan University of Medical Sciences, Isfahan, Iran. Tel: +98 313792 7060; Fax: +98 313 6680011; E-mail: v_akbari@pharm.mui.ac.ir

Received:27 Mar. 2017; $\quad$ Revised: 1 Jul. 2018; $\quad$ Accepted: 4 Jul. 2018; Published online: 11 Aug. 2018

\begin{abstract}
Background: Nisin, an effective natural food preservative, is an antimicrobial peptide produced by Lactococcus lactis. Although it has been mainly studied and developed as a potential alternative for antibiotics, other pharmacological effects of the nisin including cytotoxic and anti-tumor activity have been attracted many attentions.

Objectives: Here, we aimed to evaluate in vitro cytotoxic activity of the nisin against breast cancer cells.

Materials and Methods: The effect of temperature, $\mathrm{pH}$, and chemical composition of the medium on the yield of nisin production was evaluated. As well, the anti-proliferative effect of nisin against a breast cancer cell line (i. e., MCF-7) and a non-cancerous cell line (i.e, HUVEC) was determined using MTT assay. Furthermore, the potential of the synergistic effect of the nisin on the doxorubicin cytotoxicity was evaluated.

Results: The optimum culture condition for the nisin production by L. lactis was found to be MRS medium (pH 6.3) supplemented with the tryptone and incubation at $30^{\circ} \mathrm{C}$. MTT assay results indicate that nisin exhibits a high and selective cytotoxicity against MCF-7 cell line with IC50 value of $5 \mu \mathrm{M}$. Furthermore, a combination of nisin and doxorubicin at subinhibitory concentrations were more cytotoxic compared to either of drugs alone.

Conclusion: It could be suggested that nisin, either alone or in combination with other chemotherapeutic agents, could be a potential therapeutic for the breast cancer cells.

Keywords: Antimicrobial peptide; Breast cancer; Cytotoxicity; Nisin, Lactococcus lactis.
\end{abstract}

\section{Background}

Breast cancer is the most common cancer among women worldwide. Approximately, $12 \%$ of U.S. women will develop invasive breast cancer during their lifetime. Breast cancer is the second leading cause of death of cancer in women after lung cancer (1). Different therapeutic strategies, including surgery, radiotherapy, chemotherapy, hormone therapy, and biological therapy are currently used for the treatment of breast cancer (2). However, the discovery and development of novel alternative or synergistic anticancer agents are still required to improve the efficacy and reduction of the side effects. A large number of potential anticancer agents are under examination in preclinical and clinical studies (3), among them anticancer agents derived from the natural sources such as plants or bacteria have gained an increasing attention $(4,5)$.

Bacteriocins are bacterial proteinaceous toxins, usually peptides, with antimicrobial activity against other closely-related bacterial strains (6). Nowadays, bacteriocins are used in the food industry (as preservatives) (7), agriculture (as inhibitors of the plant and animal pathogens) (8) and medicine (9). Among bacteriocins, nisin is the only one approved by FDA

Copyright (C) 2017 The Author(s); Published by National Institute of Genetic Engineering and Biotechnology. This is an open access article, distributed under the terms of the Creative Commons Attribution-NonCommercial 4.0 International License (http://creativecommons.org/licenses/ by-nc/4.0/) which permits others to copy and redistribute material just in noncommercial usages, provided the original work is properly cited. 
as "Generally Regarded as Safe" (GRAS) compound for food applications (10). Nisin is a polycyclic peptide composed of 34 amino acids, which is produced by Lactococcus lactis (11). For industrial and large-scale applications, the chemical synthesis of this peptide is not cost-effective and nisin is mostly produced by the L. lactis using cheap and natural cultivation substrates (12). However, the high yield of bacteriocins production usually needs an optimized culture condition (e.g., the chemical composition of the media and physical parameters such as temperature and $\mathrm{pH})(13)$.

Nisin has different pharmacological effects including antimicrobial/biofilm, immuno-modulatory, and anticancer. Unlike other bacteriocins, nisin has effective antibacterial activity against a broad spectrum of Grampositive and Gram-negative bacteria (14). However, nisin exhibited lower antibacterial activity against certain Gram-negative bacteria (15). Because of its unique antimicrobial properties, it can inhibit the growth of drug-resistant bacterial strains and biofilm formation (16). Furthermore, as a cationic and amphiphilic peptide, nisin shares similar physicochemical properties with host defense peptides which regulate innate immune response (17). Both in vitro and in vivo studies have shown that nisin can modulate innate immune system by inducing secretion of the chemokines and suppressing lipopolysaccharide stimulated cytokines (18). The cytotoxic and antitumor properties of nisin were explored in head and neck squamous cell carcinoma (HNSCC) in vitro and in vivo (19). Recently, Preet et al. have reported the synergistic effect of the combination of nisin and doxorubicin against murine skin carcinogenesis (20). Other group have evaluated the cytotoxic effect of the nisin on the intestinal epithelial cells in vitro and have reported a mild cytotoxic effect (IC50 $=90 \mu \mathrm{M})(21)$. Anti-proliferative and apoptotic effect of nisin on colon cancer cells (SW480) has been recently evaluated (22). Ahmadi et al. assessed the mechanism of the apoptotic effect of nisin on the colon adenocarcinoma cell line by real-Time PCR and western blotting method. They found that nisin provokes intrinsic pathway of apoptosis and increases the bax/bcl-2 ratio in the cancer cells (22).

The evidence from these studies suggests that nisin may be a good potential anti-cancer agent. However, to the best of our Knowledge, no study has the evaluated cytotoxic effect of the combination of nisin and doxorubicin against breast cancer cells.

\section{Objectives}

Considering a large number of nisin potentials for therapeutic applications, various strategies for the production of this peptide at suitable amounts and low costs were proposed. Here, we studied the effects of some physical parameters (temperature and $\mathrm{pH}$ ) and chemical composition of MRS medium on the yield of the nisin production by L. lactis. Furthermore, the present study has evaluated the potential anticancer activity of nisin against a breast cancer cell line (MCF7) and a non-cancerous cell line (HUVEC).

\section{Materials and Methods}

\subsection{Chemicals}

The chemicals used in cell culture assays were obtained from Gibco (Scotland) via local vendors. Other chemicals and reagents used in this work were of analytical grade and were purchased from Merck (Darmstadt, Germany).

\subsection{Microorganisms}

Nisin producer microorganism, L. lactis subsp. Lactis (PTCC 1336) and Escherichia coli (PTCC 1330), as an indicator microorganism, were obtained from the Persian Type Culture Collection, Iran, Tehran. L. lactis and $E$. coli were subcultured on trypticase soy yeast extract and nutrient agar plates and were incubated at 30 and $37^{\circ} \mathrm{C}$, respectively.

\subsection{Optimization of the Medium, $p H$, and Temperature} for Nisin Production

A single colony of L. lactis was inoculated into $5 \mathrm{~mL}$ of de Man, Rogosa and Sharpe (MRS) medium and incubated at $37^{\circ} \mathrm{C}$ and $100 \mathrm{rpm}$ for $16 \mathrm{~h}$. This sample was subcultured twice on the same medium to prepare the pre-culture. The pre-culture was used to inoculate $(10 \% \mathrm{v} / \mathrm{v}) 10 \mathrm{~mL}$ of the fresh medium and incubated for $48 \mathrm{~h}$. The next day, $5 \mathrm{~mL}$ of the fresh medium was added to each culture and incubated overnight. For optimization of nisin production, cultivations were performed under different $\mathrm{pH}(3.85,4.7,5.65,6.3$ or 7.5$)$, temperatures $\left(25,30\right.$ or $\left.37^{\circ} \mathrm{C}\right)$ and different supplements (triptone, casein, yeast extract, lactose, sucrose or Tween 80) were added to the MRS medium. At the final cultivation time, cell density $\left(\mathrm{OD}_{600}\right)$ and $\mathrm{pH}$ of each sample were measured.

\subsection{Recovery of Nisin by $\mathrm{pH}$-Mediated Cell Adsorption- Desorption}

The samples were acidified with $\mathrm{HCl}$ to $\mathrm{pH}$ 2, following to boiling for $10 \mathrm{~min}$ to bring nisin into the aqueous phase. Then, each sample was centrifuged at 7,500 $\times \mathrm{g}$ for $10 \mathrm{~min}$ and the supernatant the cell-free supernatant (CFS) was collected. To prepare inactivated CSF (iCSF), after extraction of nisin by setting $\mathrm{pH}$ to 2 , the 
$\mathrm{pH}$ was adjusted to 11 , following to heating at $63{ }^{\circ} \mathrm{C}$ for $30 \mathrm{~min}$. This alkaline heating led to rapid inactivation of nisin. The $\mathrm{pH}$ of CFS and iCSF were adjusted to 6 and then the supernatants were filter-sterilized through a $0.22 \mu \mathrm{m}$ membrane filter.

\subsection{Indirect Determination of the Nisin Concentration by Antimicrobial Activity}

The agar diffusion bioassay is a highly sensitive (less than $0.0125 \mu \mathrm{g} \cdot \mathrm{mL}^{-1}$ ), simple and cost-effective method widely used for the quantification of nisin (23). The titers of the produced nisin in the culture broth were measured indirectly by disc diffusion method (24). Briefly, sterile paper discs ( $6 \mathrm{~mm}$ diameter) were placed on the Mueller-Hinton agar (MHA) plates inoculated with $E$. coli. Fifty $\mu \mathrm{L}$ of the standard nisin (Sigma, USA), CFS or iCSF (negative control) were added to the paper discs and incubated overnight at $37^{\circ} \mathrm{C}$. The same solvent (MRS) was used to dissolve the powder of standard nisin and to dilute the known (standard nisin) and unknown samples (CFS). The next day, the diameter of inhibition zone was measured to the nearest $0.1 \mathrm{~mm}$ by the means of a ruler. A calibration curve was plotted based on the relationship between standard nisin concentration and zone of inhibition diameter. The concentrations of nisin in the CSFs were calculated from a linear equation of the calibration curve.

\subsection{Tricine-SDS-PAGE}

CFSs were analyzed by Tricine-sodium dodecyl sulfate-polyacrylamide gel electrophoresis (TricineSDS-PAGE) as described previously (25). For sample preparation, $5 \mu \mathrm{L}$ of a $5 \mathrm{X}$ gel loading buffer $(0.25 \mathrm{M}$ tris$\mathrm{HCl}, \mathrm{pH}$ 6.8, $5 \%$ glycerol, $5 \%$ 2-mercaptoethanol, 3 $\%$ SDS, and $0.2 \mathrm{mg}^{\mathrm{mL}} \mathrm{mL}^{-1}$ bromophenol blue) was added to $20 \mu \mathrm{L}$ of CSF and were heated to $95^{\circ} \mathrm{C}$ for $5 \mathrm{~min}$. Samples were then loaded on a tricine gel consisting of a stacking gel containing 4\% acrylamide, a spacer gel containing $10 \%$ acrylamide, and a separation gel containing $16.5 \%$ acrylamide. The gel was run at $80 \mathrm{~V}$ for $3 \mathrm{~h}$ and stained with Coomassie Blue R-250. The concentration of nisin in the sample was also measured by densitometry analysis of acrylamide gels using TL120 software (Nonlinear Inc, Durham NC, USA). Bovine serum albumin samples with known concentrations were used as standards to estimate nisin concentration on gels.

\subsection{Cell Culture}

The human breast carcinoma cell line MCF-7 and human umbilical vein endothelial cells (HUVEC) were obtained from the Pasture Institute of Iran, Tehran. Cells were grown in the Roswell Park Memorial Institute (RPMI) 1,640 medium supplemented with $10 \%$ (v/v) fetal bovine serum (FBS), 100 IU.mL $\mathrm{mL}^{-1}$ penicillin and $100 \mu \mathrm{g} \cdot \mathrm{mL}^{-1}$ streptomycin in a humidified atmosphere containing $5 \% \mathrm{CO}_{2}$ at $37^{\circ} \mathrm{C}$.

\subsection{Cytotoxicity Assays}

The cytotoxic effect of nisin was evaluated against MCF-7 (a cancerous cell) and HUVEC (a normal cell) cells by MTT [3-(4,5-dimethyl-2-thiazolyl)-2,5diphenyl-2H-tetrazolium bromide] assay as described previously (26). In brief, log-phase cells were seeded (1 $\times 10^{4} /$ well) in 96-well cell culture plates and incubated for overnight. The next day, $20 \mu \mathrm{L}$ of the prepared concentrations of the produced nisin and commercial nisin $\left(0.39-25 \mu \mathrm{g} . \mathrm{mL}^{-1}\right)$ was added to each well and incubated for a further $48 \mathrm{~h}$. The standard nisin (Sigma, USA) was dissolved in MRS medium and phosphate buffer saline to evaluate the effect of medium or other interfering materials on cytotoxicity of nisin. Every plate that also had cells treated with MRS medium, PBS and iCSF as negative controls. Cells treated with doxorubicin were used as the positive control. Furthermore, cells were incubated with the combined concentrations of the doxorubicin and nisin (10 $\left.\mu \mathrm{g} . \mathrm{mL}^{-1}\right)$. To evaluate cell viability, cells were incubated with MTT at $37{ }^{\circ} \mathrm{C}$ for $3 \mathrm{~h}$. Then, dimethyl sulfoxide (DMSO) was added to dissolve MTT-formazan crystals and the absorbance was measured at $570 \mathrm{~nm}$ by a plate reader. The percentage of cell viability was determined according to the following equation:

$\%$ Cell survival $=$ Absorbance in drug treated wells $/$ Absorbance in negative control well * 100

\subsection{Cell Morphology Analysis}

Changes in the cell morphology were evaluated to determine the effect of nisin on cell lysis and apoptosis. The morphology of cells was observed before and after each treatment using an optical microscope $(200 \times$ magnification, Nikon, Japan).

\subsection{Statistical Analysis}

Each assay was repeated three times to ensure reproducibility of the results. All data are expressed as the mean \pm standard deviation. Comparisons between two groups were analyzed by Student's t-test, and those between multiple groups were evaluated by analysis of variance (one-way ANOVA) followed by Tukey's HSD post Hoc test to evaluate intergroup significance using SPSS version 16 . The $p$ values $<0.05$ were considered significant. 


\section{Results}

4.1. Optimization of the Medium, $p H$, and Temperature for Nisin Production

The effect of different $\mathrm{pH}$ of the medium $(3.85,4.7$, $5.65,6.3$ or 7.5 ) on nisin production was evaluated and the maximum production of nisin occurred when the pH of 6.3 was used (Fig. 1A). The effect of cultivation temperature $\left(25,30\right.$ or $\left.37^{\circ} \mathrm{C}\right)$ on the titer of nisin was investigated and the maximum nisin production was observed when culture was incubated at $30{ }^{\circ} \mathrm{C}$ (Fig. 1B). The effect of different supplements (tryptone, casein, yeast extract, lactose, sucrose or Tween 80) on nisin production was evaluated and more nisin production was observed when tryptone, casein or Tween 80 was added to MRS medium (Fig. 1C). Under
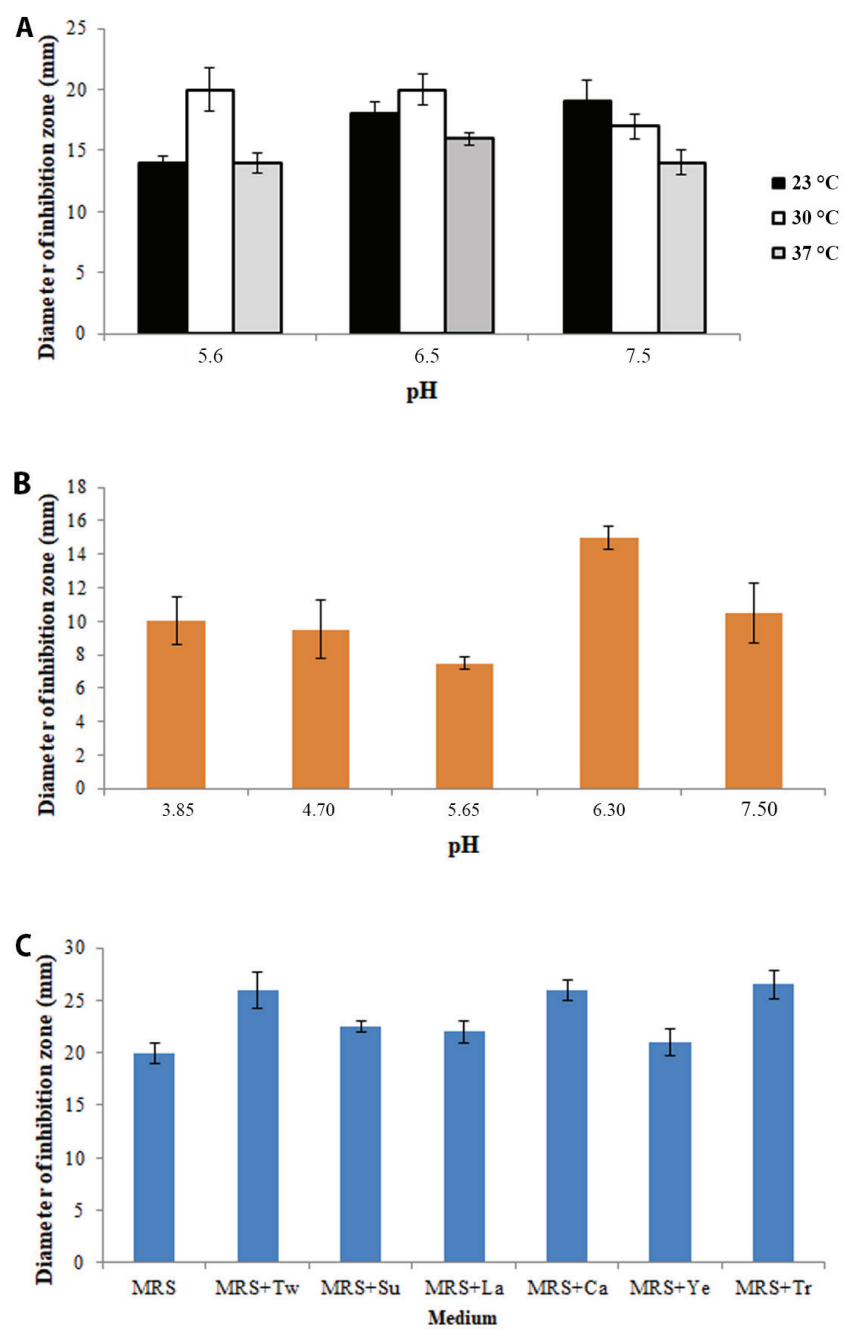

Figure 1. Optimization of the culture conditions for production of nisin by L. lactis. A) The effect of growth temperature, B) The effect of medium $\mathrm{pH}$ and C) The effect of medium supplements

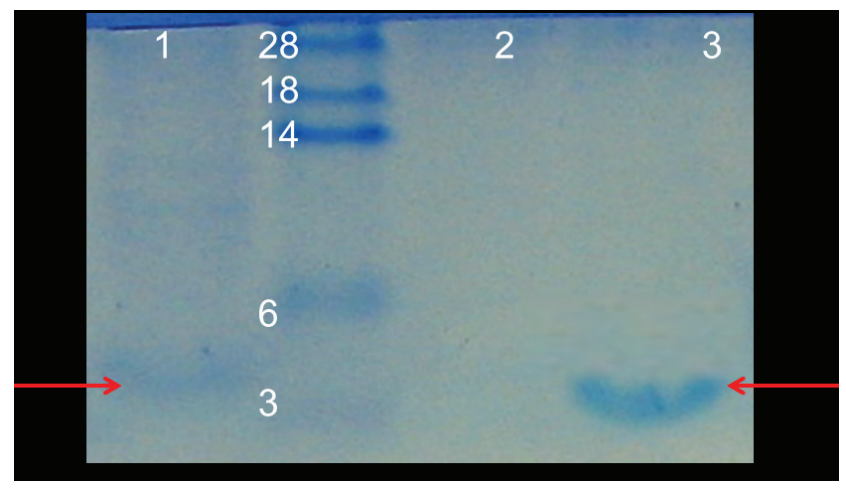

Figure 2. Tricine-SDS-PAGE analysis. Lanes 1: Cell free supernatant from L. lactis; 2: negative control; 3: standard nisin (Sigma, USA). Nisin ( $3.5 \mathrm{kDa})$ is denoted by the arrows

optimum cultural conditions, using MRS medium ( $\mathrm{pH}$ 6.3) supplemented with tryptone and incubation at 30 ${ }^{\circ} \mathrm{C}$, the titer of $1100 \mathrm{IU} \cdot \mathrm{mL}^{-1}$ was obtained for nisin (based on the standard curve of nisin, Supplementary Fig. 1).

\subsection{Tricine-SDS-PAGE of the Partially Purified Nisin}

The apparent molecular weight of bacteriocin produced by L. lactis was estimated by tricine-SDS-PAGE. As shown in Figure 2, the envisioned molecular weight of the partially purified nisin was approximately $3.5 \mathrm{kDa}$, which was located at the same locus of commercial nisin (Sigma, USA) in tricine-SDS-PAGE.

\subsection{In vitro Cytotoxicity of Nisin}

The cytotoxicity of nisin against MCF-7 and HUVEC cells was evaluated using MTT assay. The viability of MCF-7 cells decreased from 87 to $46 \%$ in a concentration-dependent of nisin from 0.39 to 25 $\mu \mathrm{g} . \mathrm{mL}^{-1}$. The survival of MCF-7 cells was significantly inhibited by nisin and the IC50 value of $17 \mu \mathrm{g} \cdot \mathrm{mL}^{-1}$ was found (Fig. 3A). Anti-prolifratory effect of produced nisin on MCF-7 cell line was very close to commercial nisin dissolved in MRS medium (Supplementary Fig. 2). However, it had a little more cytotoxic effect (supplementary Fig. 2) in comparison with standard nisin dissolved in PBS which could be attributed to interfering substances presenting in MRS medium or better solubility of nisin in MRS ( $\mathrm{pH}$ 5.5).

Nisin exhibited a lower level of cytotoxicity for a normal cell line, HUVEC, with an IC50 value of 64 $\mu \mathrm{g} . \mathrm{mL}^{-1}$ (Fig. 3B). This four-fold difference in nisin cytotoxicity against MCF-7 over HUVEC cells was shown to be statistically significant in MTT assay ( $p$ $<0.05$ ).

In addition, MCF-7 and HUVEC cells were treated with 

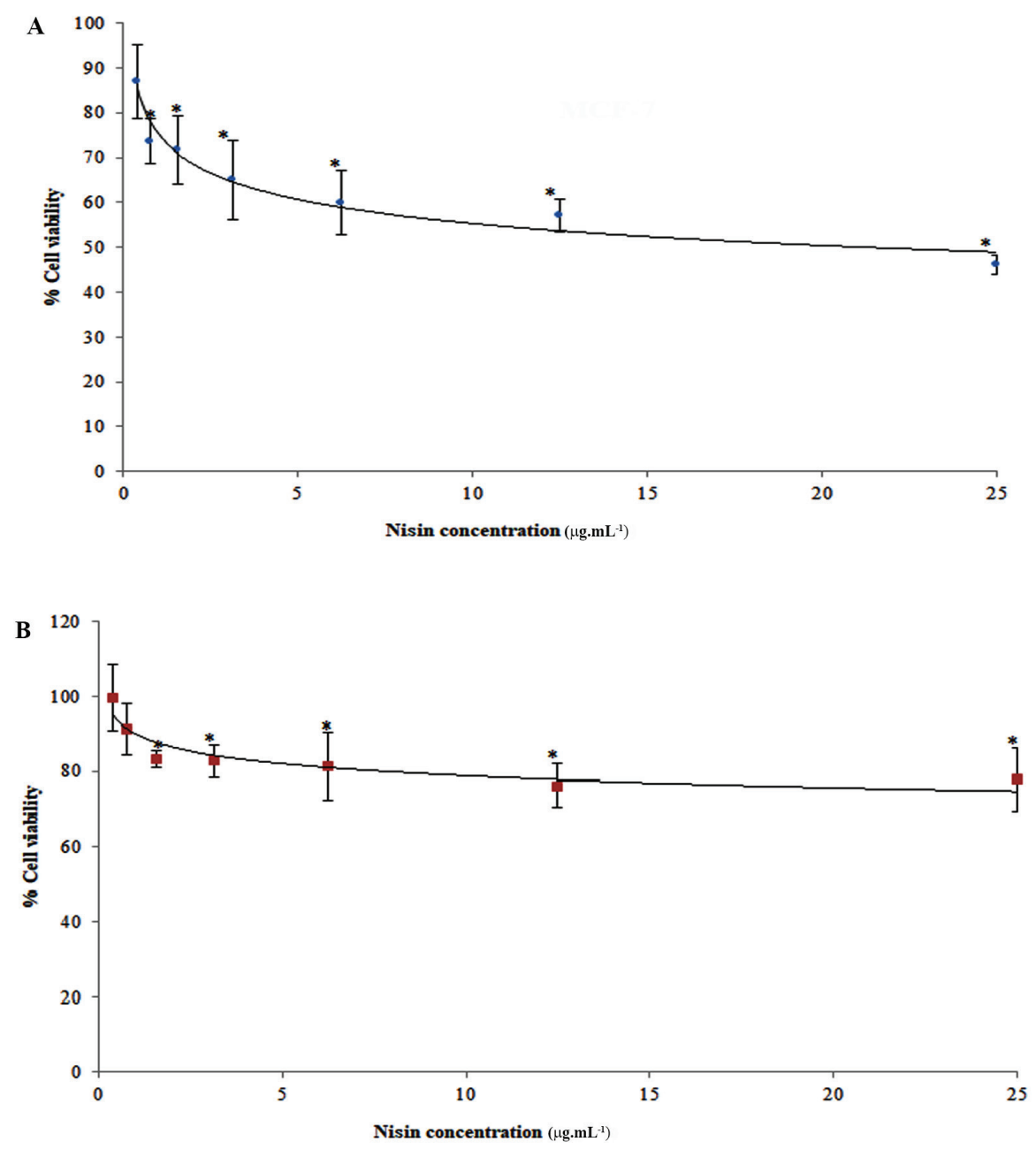

Figure 3. The effects of nisin on cell viability as determined by MTT assay. A) MCF-7 and B) HUVEC. Cells were incubated for $48 \mathrm{~h}$ with different concentrations $\left(0.39-25 \mu \mathrm{g} . \mathrm{mL}^{-1}\right)$ of nisin. The vertical bars indicate the standard deviations $(n=4)$. Asterisks indicate the means, which were significantly different $(p<0.05)$ from the control (untreated cells).

the combined concentrations of doxorubicin and nisin. It was shown that co-incubation with nisin increases the cytotoxicity of the doxorubicin (Fig. 4). This synergic effect was more significant in the lower concentration of doxorubicin and against MCF-7. Approximately, threefold higher cytotoxicity was observed when MCF-7 cells were incubated with a combination of nisin (10 $\left.\mu \mathrm{g} \cdot \mathrm{mL}^{-1}\right)$ and doxorubicin $\left(6 \mu \mathrm{g} \cdot \mathrm{mL}^{-1}\right)$ compared to doxorubicin alone $(p<0.01)$.

\subsection{Morphological Analysis}

Changes in cell morphology were evaluated using an optical microscope. The morphological analysis showed that compared to the control or untreated cells (Fig. 5A), treatment of cells with nisin $\left(0.39-25 \mu \mathrm{g} \cdot \mathrm{mL}^{-1}\right)$ led to apoptosis (Fig. 5B), but not cell lysis. However, nisin

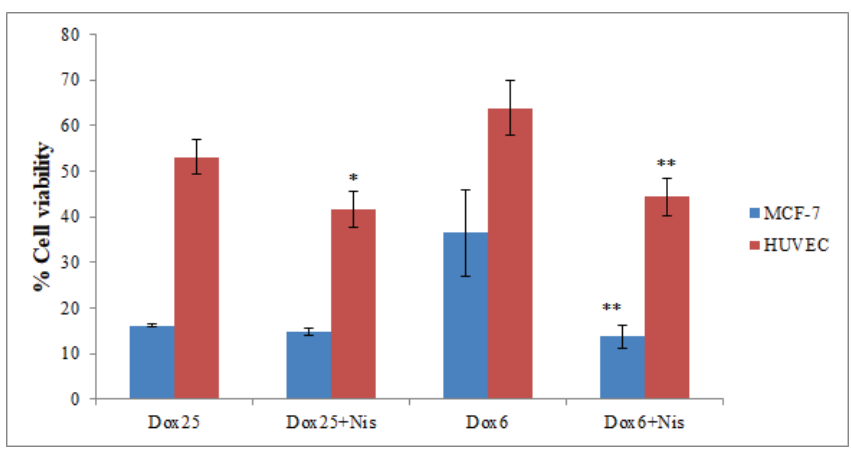

Figure 4. Cell viability of MCF-7 and HUVEC after $48 \mathrm{~h}$ of incubation with the combinations of nisin $\left(10 \mu \mathrm{g} \cdot \mathrm{mL}^{-1}\right)$ and doxorubicin $\left(6\right.$ or $\left.25 \mu \mathrm{g} \cdot \mathrm{mL}^{-1}\right)$. The vertical bars indicate the standard deviations $(n=4)$. Asterisks indicate the means which were significantly different $(p<0.05)$ from the control (cells were incubated with doxorubicin alone). 
A
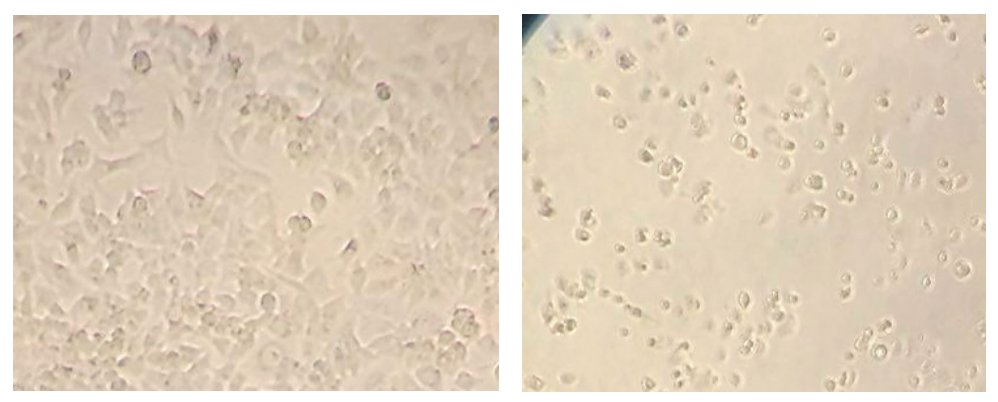

$\mathrm{C}$

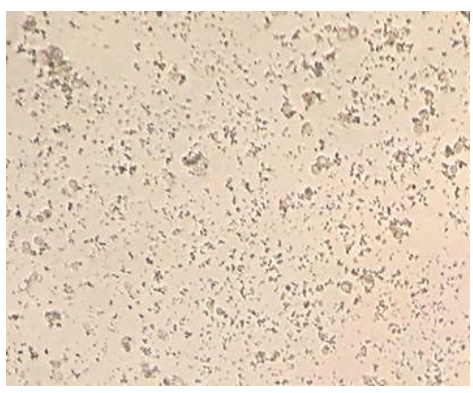

Figure 5. The morphological analysis of the MCF-7 cells using optical microscopy. A) untreated cells, B) cells treated with doxorubicin $\left(6 \mu \mathrm{g} \cdot \mathrm{mL}^{-1}\right)$, and $\left.\mathbf{C}\right)$ cells treated with a combination of nisin $\left(10 \mu \mathrm{g} \cdot \mathrm{mL}^{-1}\right)$ and doxorubicin $\left(6 \mu \mathrm{g} \cdot \mathrm{mL}^{-1}\right)$.

in combination with doxorubicin results in a significant cell lysis (Fig. 5C).

\section{Discussion}

Like other bacteriocins, culture conditions such as cultivation temperature, $\mathrm{pH}$, and composition of the medium could influence the yield of nisin production. Depending on the bacterial strains and medium which was used, different additives, optimization of the $\mathrm{pH}$, and cultivation temperatures can be applied. In this study, the maximum production of nisin was acquired when MRS medium with $\mathrm{pH}$ of 6.3 was used. The initial $\mathrm{pH}$ of the medium significantly influences the L. lactis growth rate; a lactic acid producer bacterium, as well as the titer of nisin production. However, the optimum $\mathrm{pH}$ for the nisin production was lower than the optimum $\mathrm{pH}$ for bacterial growth (data were not shown). The maximum nisin production was observed when L. lactis was cultivated at $30{ }^{\circ} \mathrm{C}$. Similar to our results, other groups have found the optimal production of nisin when L. lactis was cultured in a lactose-based medium with pH 6 at $31{ }^{\circ} \mathrm{C}$ (27).

Another critical factor influencing the production of nisin is the medium compositions. The effect of different supplements (tryptone, casein, yeast extract, lactose, sucrose, or Tween 80) on nisin production was evaluated and a higher amount of nisin production was observed when tryptone, casein or Tween 80 was added to the MRS medium. We found that additional nitrogen source such as tryptone and casein have more influence on nisin production compared with that of carbon source supplements (sucrose and lactose). It could be explained based on strict and specific nutritional requirements of the lactic acid bacteria for their growth (28).

The produced nisin under optimum cultural conditions was partially purified using $\mathrm{pH}$-mediated cell adsorption-desorption method to extract cell-bound nisin. Because of its basic nature $(p I>9)$ nisin has more solubility under acidic $\mathrm{pH}$. At neutral $\mathrm{pH}$, produced nisin is associated with cell membrane but when $\mathrm{pH}$ decreased it desorbs and release into the medium. Zhang et al. also used a pH-based extraction method to purify pentocin 31-1 produced by Lactobacillus pentosus (29). They effectively purified this bacteriocin with a high increase in the specific activity after adsorption at $\mathrm{pH} 4.5$ and release at $\mathrm{pH}$ 7.0.

Nisin is a safe and food grade bacteriocin which has growing potential application in medicine. There is some evidence suggesting a potential anticancer effect of nisin. In the present study, cytotoxic activity of nisin against MCF-7 and HUVEC cells were evaluated using MTT assay. Interestingly, this effect was cell type dependent and a lower toxicity was observed for HUVEC, a normal cell line. Similar results were also reported by Joo et al. They observed that in contrast to HNSCC cell line, normal oral keratinocytes were not significantly affected by nisin treatment $\left(80 \mu \mathrm{g} . \mathrm{mL}^{-1}\right)$ (30).

The selectivity of nisin for cancer cells could be explained based on membrane differences. Tumor cells usually carry a net negative charge as they contain more anionic molecules such as phosphatidylserine in the cell membrane $(31,32)$. In contrast, normal cells have an overall neutral charge as their membrane compound mainly composed of zwitterionic lipids (e.g., sphingomyelin, phosphatidylethanolamine, and phosphatidylcholine) (33). As an antimicrobial peptide, nisin has both cationic and hydrophobic characteristics and can interact with both the negatively charged heads and the lipophilic tail of cell membrane phospholipids (34). The electrostatic interactions between cationic nisin and anionic membrane of cancer cells may play a 
major role in the selective cytotoxicity of this peptide.

The exact mechanism of anti-cancer effect of nisin remains to be explained. Some studies have suggested several mechanisms including cell membrane disruption and pore formation, altering the level of intracellular ions (e.g., calcium), changing the transmembrane potential, induction of cell cycle arrest, and apoptosis $(30,35)$. Recently it was demonstrated that nisin induces calcium-dependent apoptosis of the HNSCC cells via calpain but independent of caspase-3 cleavage (19). We found that nisin has a high cytotoxic effect (IC50 $=17 \mu \mathrm{g} \cdot \mathrm{mL}^{-1}$ or $5 \mu \mathrm{M}$ ) against MCF-7, a caspase3-deficient cell line (36). However, a previous study which evaluated the cytotoxicity of the nisin against human colorectal cell lines reported a higher IC50 (21). It could be hypothesized that caspase- 3 negative cancer cells are more sensitive to the anticancer effect of nisin. However, further studies are still required to explore the exact nisin mode of action.

Interestingly, nisin can significantly enhance the cytotoxic effect (approximately three folds) of an anticancer drug, doxorubicin. This peptide could increase uptake of doxorubicin by cancer cells via destabilization of the cellular membrane or poreformation. In the present study, morphological analysis has revealed that combination of nisin and doxorubicin results in the cell disruption and lysis. In agreement with our results, other groups have reported the synergistic cytotoxic effect of the combination of doxorubicin and $\alpha$-helical peptides against HeLa and HepG2 cell lines (37). They evaluated the possible mechanism of this synergy using scanning electron and fluorescence microscopy. They observed that co-administration of doxorubicin and $\alpha$-helical peptides enhanced cellular uptake of doxorubicin as a result of altering membrane integrity, cavity formation, and loss of microvilli (37). Many other antimicrobial peptides have exhibited anticancer effects. However, nisin because of its unique mode of action and safety has attracted many attentions. In addition to the cytotoxic agent, nisin can act as an immuno-modulator agent so co-administration of nisin with other chemotherapeutic agents might improve patient response and decrease adverse inflammatory effects.

In conclusion, our study reported the effective cytotoxic effects of nisin against MCF-7, a breast cancer cell line. Furthermore, nisin exhibited a selective toxicity against cancerous cells in comparison to HUVEC, a normal cell line. Most importantly, a combination of nisin with doxorubicin led to synergetic anticancer effect. It could be suggested that a combination of nisin and doxorubicin at sub-inhibitory concentrations can be a potential treatment for the breast cancer, thereby reducing side effects of anticancer drug and improving its therapeutic index; however more studies including in vitro and in vivo studies need to be performed.

\section{Acknowledgment}

This work was supported by the Isfahan University of Medical Sciences (grant no. 394995)

\section{Spplementary Data}

This paper includes two supplementary files containing the standard curve of nisin (File 1) and the antiprofilatory effect of standard nisin dissolved in MRS or BPS on MCF-7 cells which are appeared on the web site of the IJB journal (http://www.ijbiotech. com).

\section{References}

1. U.S. Breast Cancer Statistics. Breastcancer.org. 2016. avaible from: http://www.breastcancer.org/symptoms/ understand_bc/ statistics

2. Senkus E, Kyriakides S, Penault-Llorca F, Poortmans P, Thompson A, Zackrisson S, et al. Primary breast cancer: ESMO Clinical Practice Guidelines for diagnosis, treatment and follow-up. Ann Oncol. 2013:1-17. doi:10.1093/annonc/mdt284

3. Tryfonidis K, Senkus E, Cardoso MJ, Cardoso F. Management of locally advanced breast cancer [mdash] perspectives and future directions. Nat Rev Clin Oncol. 2015;12(3):147-62. doi:10.1038/nrclinonc.2015.13

4. Cragg GM, Newman DJ. Plants as a source of anti-cancer agents. J Ethnopharmacol. 2005;100(1):72-79. doi:10.1016/j. jep.2005.05.011

5. Mukhtar E, Adhami VM, Mukhtar H. Targeting microtubules by natural agents for cancer therapy. Mol Cancer Ther. 2014;13(2):275-284. doi:10.1158/1535-7163.MCT-13-0791

6. Daw MA, Falkiner FR. Bacteriocins: nature, function and structure. Micron. 1996;27(6):467-479. doi:10.1016/S09684328(96)00028-5

7. O'sullivan L, Ross R, Hill C. Potential of bacteriocin-producing lactic acid bacteria for improvements in food safety and quality. Biochimie. 2002;84(5):593-604. doi:10.1016/S03009084(02)01457-8

8. Svetoch E, Stern N. Bacteriocins to control Campylobacter spp. in poultry-a review. Poult Sci. 2010;89(8):1763-1768. doi:10.3382/ps.2010-00659

9. Sang Y, Blecha F. Antimicrobial peptides and bacteriocins: alternatives to traditional antibiotics. Anim Health Res Rev. 2008;9(02):227-235. doi:10.1017/S1466252308001497

10. Cleveland J, Montville TJ, Nes IF, Chikindas ML. Bacteriocins: safe, natural antimicrobials for food preservation. Int $J$ Food Microbiol. 2001;71(1):1-20. doi:10.1016/S01681605(01)00560-8

11. Rodriguez J. Review: Antimicrobial spectrum, structure, properties and mode of action of nisin, a bacteriocin produced by Lactococcus lactis. Food Sci Technol Int. 1996;2(2):61-68. doi:10.1177/108201329600200202

12. Ongey EL, Neubauer P. Lanthipeptides: chemical synthesis 
versus in vivo biosynthesis as tools for pharmaceutical production. Microb Cell Fact. 2016; 15: 1-16. doi:10.1186/ s12934-016-0502-y

13. Parente E, Ricciardi A. Production, recovery and purification of bacteriocins from lactic acid bacteria. Appl Microbiol Biotechnol. 1999;52(5):628-638. doi:10.1007/s002530051570

14. Yeaman MR, Yount NY. Mechanisms of antimicrobial peptide action and resistance. Pharmacol Rev. 2003;55(1):27-55. doi:10.1124/pr.55.1.2

15. Helander IM, Mattila-Sandholm T. Permeability barrier of the Gram-negative bacterial outer membrane with special reference to nisin. Int J Food Microbiol. 2000;60(2):153-161. doi:10.1124/pr.55.1.2

16. Qi X, Poernomo G, Wang K, Chen Y, Chan-Park MB, Xu R, et al. Covalent immobilization of nisin on multi-walled carbon nanotubes: superior antimicrobial and anti-biofilm properties. Nanoscale. 2011;3(4):1874-1880. doi:10.1039/C1NR10024F

17. Hancock RE, Haney EF, Gill EE. The immunology of host defence peptides: beyond antimicrobial activity. Nat Rev Immunol. 2016;16(5):321-334. doi:10.1038/nri.2016.29

18. Kindrachuk J, Jenssen H, Elliott M, Nijnik A, MagrangeasJanot L, Pasupuleti M, et al. Manipulation of innate immunity by a bacterial secreted peptide: lantibiotic nisin $\mathrm{Z}$ is selectively immunomodulatory. Innate Immun. 2013;19(3):315-327. doi:10.1177/1753425912461456

19. Kamarajan P, Hayami T, Matte B, Liu Y, Danciu T, Ramamoorthy A, et al. Nisin ZP, a bacteriocin and food preservative, inhibits head and neck cancer tumorigenesis and prolongs survival. PloS one. 2015;10(7):1-20. doi:10.1371/journal.pone.0131008

20. Preet S, Pandey S, Saini N, Koul A, Rishi P. Nisin Augments Doxorubicin Permeabilization and Ameliorates Signaling Cascade during Skin Carcinogenesis. Transl Med. 2015;6(161). doi:10.4172/2161-1025.1000161.

21. Maher S, McClean S. Investigation of the cytotoxicity of eukaryotic and prokaryotic antimicrobial peptides in intestinal epithelial cells in vitro. Biochem Pharmacol. 2006;71(9):12891298. doi:10.1016/j.bcp.2006.01.012.

22. Ahmadi S, Ghollasi M, Hosseini HM. The apoptotic impact of nisin as a potent bacteriocin on the colon cancer cells. Microb Pathog. 2017;111:193-197. doi:10.1016/j.micpath.2017.08.037.

23. Pongtharangkul T, Demirci A. Evaluation of agar diffusion bioassay for nisin quantification. Appl Microbiol Biotechnol. 2004;65(3):268-272. doi:10.1007/s00253-004-1579-5.

24. Abedi D, Feizizadeh S, Akbari V, Jafarin-Dehkordi A. In vitro anti-bacterial and anti-adherence effects of Lactobacillus delbrueckii subsp bulgaricus on Escherichia coli. Res Pharm Sci. 2013;8(4):260-268.

25. Schägger H, Von Jagow G. Tricine-sodium dodecyl sulfatepolyacrylamide gel electrophoresis for the separation of proteins in the range from 1 to $100 \mathrm{kDa}$. Anal Biochem. 1987;166(2):368379. doi:10.1016/0003-2697(87)90587-2

26. Akbari V, Sadeghi HMM, Jafarian-Dehkordi A, Abedi D, Chou CP. Improved biological activity of a single chain antibody fragment against human epidermal growth factor receptor 2 (HER2) expressed in the periplasm of Escherichia coli. Protein Expr Purif. 2015;116:66-74. doi:10.1016/j.pep.2015.07.005

27. Meghrous J, Huot E, Quittelier M, Petitdemange H. Regulation of nisin biosynthesis by continuous cultures and by resting cell of Lactococcus lactis subsp. lactis. Res Microbiol. 1992;143(9):879-890. doi:10.1016/0923-2508(92)90075-Y

28. Hébert EM, Raya RR, Savoy de Giori G. Evaluation of minimal nutritional requirements of lactic acid bacteria used in functional foods. In: Walker JM, Spencer JFT, Spencer ALRd, editors. Environmental Microbiology: Methods and Protocols,vol. 16.New Jersey, USA: Humana Press; 2004. pp. 139-148. doi:10.1385/1-59259-765-3:139

29. Zhang J, Liu G, Shang N, Cheng W, Chen S, Li P. Purification and partial amino acid sequence of pentocin 31-1, an antiListeria bacteriocin produced by Lactobacillus pentosus 311. J Food Prot. 2009;72(12):2524-1529. doi:10.4315/0362$028 \mathrm{X}-72.12 .2524$

30. Joo NE, Ritchie K, Kamarajan P, Miao D, Kapila YL. Nisin, an apoptogenic bacteriocin and food preservative, attenuates HNSCC tumorigenesis via CHAC1. Cancer Med. 2012;1(3):295-305. doi:10.1002/cam4.35

31. Szachowicz-Petelska B, Dobrzyńska I, Skrodzka M, Darewicz B, Figaszewski ZA, Kudelski J. Phospholipid Composition and Electric Charge in Healthy and Cancerous Parts of Human Kidneys. J Membr Biol. 2013;246(5):421-425. doi:10.1007/ s00232-013-9554-7

32. Dobrzynska I, Skrzydlewska E, Figaszewski ZA. Changes in electric properties of human breast cancer cells. J Membr Biol. 2013;246(2):161-166. doi:10.1007/s00232-012-9516-5

33. Yamaji-Hasegawa A, Tsujimoto M. Asymmetric distribution of phospholipids in biomembranes. Biol Pharm Bull. 2006;29(8):1547-1553. doi:10.1248/bpb.29.1547

34. Hwang PM, Vogel HJ. Structure-function relationships of antimicrobial peptides. Biochem Cell Biol. 1998;76(2-3):235246. doi:10.1139/098-026

35. Moll GN, Clark J, Chan WC, Bycroft BW, Roberts GC, Konings $\mathrm{WN}$, et al. Role of transmembrane $\mathrm{pH}$ gradient and membrane binding in nisin pore formation. J Bacteriol. 1997;179(1):135140. doi:10.1128/jb.179.1.135-140.1997

36. Kagawa S, Gu J, Honda T, McDonnell TJ, Swisher SG, Roth JA, et al. Deficiency of Caspase-3 in MCF7 Cells Blocks Baxmediated Nuclear Fragmentation but not Cell Death. Clin Cancer Res. 2001;7(5):1474-1480. doi:10.1186/bcr463

37. Zhao J, Huang Y, Liu D, Chen Y. Two hits are better than one: synergistic anticancer activity of $\alpha$-helical peptides and doxorubicin/epirubicin. Oncotarget. 2015;6(3):1769-1778. doi:10.18632/oncotarget.2754 